\title{
THE ROLE OF CLUSTERS AND JOINT MARKETING ALLIANCES IN FACILITATION OF THE FOREIGN MARKET ENTRY (THE EXAMPLE OF SLOVAK WINERIES)
}

\author{
Tatiana Hluškováa, Mária Šášikováb \\ ${ }^{\text {a }}$ Doctoral student, University of Economics in Bratislava, Department of International Trade, Dolnozemská cesta 1, Brati- \\ slava, Slovakia, tatiana.hluskova@gmail.com \\ ${ }^{\text {b}}$ Doctoral student, University of Economics in Bratislava, Department of International Trade, Dolnozemská cesta 1, \\ Bratislava, Slovakia, sasikova.m@gmail.com
}

\section{ARTICLE INFO}

JEL classification: M31, Q13, Q17

Keywords:

- wineries

- joint marketing alliance

- cluster

- export

\section{ABSTRACT}

The purpose of the paper is to investigate, how marketing alliance or clusters of Slovak wineries could affect their exports and what impact could such partnerships have on their image abroad. The aim is to ascertain the opinions of Slovak winemakers on export and cooperation by means of questionaire survey. The paper deals with clusters, their functioning in Slovak environment, wine clusters and marketing alliances outside Slovakia. It also draws conclusions from the survey. According to its results, Slovak wineries recognize the benefits of cooperation. The survey showed that the willingness to cooperate exist in Slovak viticulture, which is the basis needed for the creation of clusters and marketing alliances. 


\section{INTRODUCTION}

Considering Slovak wine industry is largely formed by small and medium enterprises (or even by individual winemakers), cooperation could be an appropriate way to lower the costs and risks of export. Even though the amount of wine set for export would be limited due to the relatively small acreage of vineyards, Slovak wines are the high quality ones (as they received a number of awards in the international contests lately). The important precondition for the foreign market success would be to raise awareness about Slovak wines abroad.

Given the limited resources of many of the Slovak winemakers, the coordination of their marketing efforts (or even the creation of "Brand Slovakia") by means of marketing alliance might be the suitable solution. Another possible way of cooperation is the creation of clusters, based on the geographical proximity of winemakers, grape growers and other entities associated with the viticulture. In the case of active cooperation between its members, a cluster can also become a strategic alliance. Both the clusters and alliances could contribute to the growth of competitiveness of the Slovak winemakers abroad. Nevertheless, their positive impacts will depend on the willingness and the ability of their members to cooperate and coordinate their actions.

\section{A. The theory of clusters}

Various authors provide their own definitions of clusters. Porter defined clusters as "geographic concentrations of interconnected companies and institutions in a particular field" (Porter 1998). Clusters include suppliers of specialized inputs such as components, machinery, and services, and providers of specialized infrastructure. Many clusters could include governmental and other institutions - such as universities, standard-setting agencies, think tanks, vocational training providers, and trade associations - that provide specialized training, education, information, research, and technical support. The California wine cluster is a good example. It includes more than $680 \mathrm{com}$ mercial wineries, as well as several thousand independent grape growers.

According to Piore and Sable, cluster is "an aggregation of comparative companies performing in an industrial area in a scheme of competitive and cooperative correlation". Schmitz defines cluster as "a group of producers that are founded close to each other and forming similar products" (Chlebíková and Mráziková 2009). According to the definition of OECD, cluster is "a group of contiguous elements of a statistical population, e.g. a group of people living in a single house, a consecutive run of observations in an ordered series, or a set of adjacent plots in one part of a field" (OECD 2002).

The European Commission defines clusters as engines of economic development and the supporters of innovation in the European Union. European Commission definition says, that „a cluster is a geographically proximate group of interconnected companies and associated institutions in a particular field which:

- co-operate and compete;

- are locally concentrated within one or more regions, although they may have global presence;

- are specialized in particular industry with common technologies and skill sets" (Danube Knowledge Cluster 2013).

The European Commission defines clusters as engines of economic development and the supporters of innovation in the European Union. European Commission definition says, that „a 
cluster is a geographically proximate group of interconnected companies and associated institutions in a particular field which:

- co-operate and compete;

- are locally concentrated within one or more regions, although they may have global presence;

- $\quad$ are specialized in particular industry with common technologies and skill sets" (Danube Knowledge Cluster 2013).

\section{i. Clusters in Slovak environment}

Clusters provide a favourable business environment for enterprises, especially small and mediumsized (European Commision 2013). Programme support through the Operational Programmes of National Strategic Reference Framework for 2007 - 2013, and other programmes of the European Commission supported the formation of clusters in the Slovak regions. In Slovakia, several clusters do exist. The founding members of these clusters are public institutions (e.g. self-governing regions, municipalities, public universities). Other members of clusters are usually important research and development institutes, other educational institutions, companies and associations (Šmíd 2008). According to this still current division, clusters in Slovakia could be divided into two major groups - technological clusters and clusters of tourism (SIEA 2009):

Technological clusters

- Slovak Engineering cluster, Banská Bystrica region

- Automotive cluster - western Slovakia, Trnava region

- BITERAP cluster, Košice region

- Electrical Cluster - western Slovakia, Trnava region

- The Energy Cluster - western Slovakia, Trnava region

- $\quad A T+R$ Cluster, Prešov region

- Košice IT Valley z.p.o, Košice region

- Slovak plastics cluster, Trnava region

- Z Z@ict, Žilina region

\section{Clusters of tourism}

- Tourism cluster - western Slovakia

- Cluster LIPTOV - tourism association, Žilina region

- Cluster ORAVA - tourism association, Žilina region

- Cluster TURIEC - tourism association, Žilina region

- Tourism Association Balnea Cluster, Banská Bystrica region

Note: Danube knowledge cluster has a special position in the cluster structure of Slovakia (Danube Knowledge Cluster 2013).

Nowadays, The Business and Innovation Centre - BIC Bratislava, Ltd. is trying to start an 
initiative to establish the ICT Cluster in the western Slovakia (BIC 2013).

In 2010, the Union of Slovak clusters was established with the vision of better, prosperous, competitive and innovative regions of Slovakia. The activities of the Union include: support of information, knowledge, experience and know-how exchange among clusters, support of the participation of clusters in international events and in international projects focused on education, development, research, innovation and transfer of know-how, the organisation of training sessions, seminars, lectures and workshops, improvement of educational system according to market needs, development of studies, analyses and forecasts and support of research, product development and production innovation transfer (CluStrat 2013).

For the cluster in the Slovak Republic to be successful, it should be established by public institution (self-governing region, town, municipality, public university). Where appropriate, the cooperation with a regional workplace of the Slovak Academy of Sciences is recommended. Newly created cluster in Slovakia could be funded by public sources, if the following conditions were fulfilled:

- cluster is established by public institutions,

- cluster activity does not interfere with the development documents of the Slovak Republic.

The existence of clusters (not only in Slovakia but also in other EU countries - especially in Central Europe) is conditioned by their classical form - cooperation only within certain sectors (sectoral clusters - e.g. engineering, automotive cluster, clusters of tourism are well-known in Slovakia, too) (MSP online 2012). They were created despite the difficult situation - Slovakia does not have an appropriate legislation to define and promote clusters and, for this reason, only few clusters were established in Slovakia.

To promote innovation through new cluster concepts supporting the emerging sectors and cross-cutting themes, the National Agency for Development of Small and Medium Enterprises (NADSME) began with the implementation of the project named „Boosting innovation through new cluster concepts in support of emerging issues and cross-sectoral themes" (CluStrat) on October $1^{\text {st }}$ 2011. The project CluStrat is implemented under the Operational Programme Central Europe (CluStrat 2013). The project aims to promote innovation through new cluster concepts. The main focus of the project is on the emerging industry sectors:

- Active development of mankind and its aging

- Sustainable development and the green economy

- Sustainable Mobility

The project also aims at these cross-cutting themes:

- Gender and innovation, including aspects of diversity

- Internationalization

- Knowledge and Technology Transfer

Most of the cluster initiatives have been identified within the European Cluster Observatory initiative in countries, where science and innovation support is an important part of government policy. 
The key barriers of cluster development in the conditions of Slovak republic could be classified as follows:

- The barriers of engaging of SMEs in clusters do exist, namely: limited financial and human resources, lack of information about clustering, aversion of enterprises to risk, distrust to suppliers and to competitors, limited innovation capability of enterprises and lack of motivation for networking. An active, ongoing dialogue between companies and regional actors, access to key resources (infrastructure, skilled workforce, favourable loans), support of services requiring knowledge and technological improvements in the region of traditional industries, support of existing innovation networks, conditions for interregional cooperation, and financial resources to develop feasibility studies are all needed to eliminate these barriers (SIEA 2010).

- Support for science and innovation in the Slovak Republic is not a main priority or even a part of the government policy as much as in developed European countries, not enough attention is given to the issue of clusters, although the support of small and medium enterprises has been identified as a priority from the beginning of the 90 's.

- Substantial underinvestment of research and development (R\&D) in Slovakia - cluster initiatives sense the lack of the resources which are necessary for their efficient development.

- Slovak legislation does not define the term "cluster" and thus does not directly support clusters initiatives. Slovakia doesn't have a mechanism for the creation, development and promotion of clusters. Existing clusters in Slovakia therefore have to find the most appropriate legal form of their administrative existence within the realm of possibilities of Slovak law.

- In other countries, cluster initiatives are supported by public sector - directly by the government but also by the local governments of countries/regions. In Slovakia, cluster initiatives are supported by self-governing regions and by the private sector, but this assistance is quantified as very low by the clusters themselves.

- In addition, beside to the lack of resources, uncoordinated structure of public sector institutions could be seen as a main source of problems in development of clusters initiatives in Slovakia.

Universities, R\&D institutions, business associations and public agencies are the so-called knowledge intermediaries, as they are the entities diffusing information that can enhance the capabilities of the cluster members. They can also act as brokers in the cluster (Visser 2004). Success of the cluster may also depend on its ability of adaptation to the shocks in industry and on the ability of institutional environment to foster this adaptation (Migone and Howlett 2010).

\section{B. Strategic and marketing alliances}

There are many different definitions of strategic alliances, but all of them agree upon the basic point: strategic alliances are partnerships of two or more entities in order to gain competitive advantage. Strategic alliances enable the partner companies to make use of the opportunities that would otherwise be beyond the capabilities of a single firm. In today's highly globalized and rapidly changing markets, it is ever more difficult to create sustainable competitive advantage. 
As for the forms of strategic alliances, the opinions of American and European authors vary. In this article, we would like to divide strategic alliances into contractual agreements and equity arrangements. Contractual agreements can be formed along the whole value chain: companies can create research and development alliances, product development alliances, technological alliances, production alliances, procurement alliances, marketing alliances, distribution alliances, standard-setting alliances or service alliances. Thus, the partners in contractual alliances combine their resources only in a certain field of business activity. Equity arrangements can take form of joint ventures, minority equity alliances or equity swaps (Ferenč́ková et al. 2013).

Basic motives to create a strategic alliance are foreign market entry (often combined with the need of overcoming the legal barriers of entry), risk sharing (e.g. risk of capital intensive investment), cost sharing (e.g. R\&D costs), reaction on competitor's activities, sharing of the global resources (e.g. airport terminals) or learning from partners.

Joint marketing alliance means combining companies' marketing activities in a given market. A key feature of joint marketing alliances is that partner firms usually combine their marketing efforts by offering a unified image in the given marketplace (Teng and Das 2008). Cooperation could be used as a shortcut to knowledge that the partners would not be able to create within an acceptable time or at acceptable costs themselves, e.g. the knowledge about foreign markets, distribution channels or consumers (Das and Teng 2000). Coordination among partners could extend outside the field of marketing into research, product development or production.

Since the products of the food and beverages industry are becoming more and more standardized, marketing strategy based on particular regions (or even countries) could be a way how to differentiate from the competitors (Calvet 2005). Industries based on the natural resources should move from comparative advantage to constructed advantage, i.e. advantage derived from the innovation and knowledge (Felzenstein, Deans and Echecopar 2012).

Even though a company could be able to enter the new markets, it may realize the need to offer a variety of products it cannot produce itself. In this case, cooperation with other firms may be a suitable solution, as one partner provides financial and human resources or knowledge needed to enter the new market and the other company could fill in the gap in the assortment (Visser, 2004).

Some wine clusters have already adopted the approach of joint marketing. The well-known Waipara wine cluster in New Zealand benefits from the willingness of growers and producers to co-finance research and marketing activities and to learn from each other, as well as to develop the regional identity and community spirit (Migone and Howlett 2010). Chilean winemakers send joint marketing delegations to foreign countries (Felzenstein 2012).

As for the marketing activities, small companies tend to cooperate with local producers on a larger scale than medium and large companies. Given this willingness to cooperate, small companies are more cluster-oriented than larger firms. The companies cooperate in marketing activities aimed to attract and subsequently strengthen the relationship with new customers (Felzenstein, Deans and Echecopar 2012). For the small and medium wineries, the economies of scale achieved in the cluster enable them to compete with larger wineries from the other regions or countries. For example, the expenses for the promotion of the Rioja wines in the main export markets reached 10 mil. $€$ in 2010 . The joint marketing expenses of the cluster facilitate the export of the smaller wineries that would be otherwise inable to commercialize their products abroad (Lareina, Gómez-Bezares and Aguado 2011). 


\section{ii. Wine clusters and marketing alliances outside Slovakia}

Clustering in the wine industry is conditioned by the specific terroirs and climate needed for the grape growing. Another important factor is the association of the particular region with the quality of wines produced there (Migone and Howlett 2010). Terroir is defined as a definite and homogeneous territory endowed with a strong identity which is characterized by the natural (soil and climate) and cultural (historical and social) resources (Mueller and Sumner 2006). In France, wines are given the indication of origin named Appellation d'Origine Contrôlée (AOC). This indication provides a competitive advantage for its holders, because AOC signalize certain level of quality related to the traditional practices and terroir (Calvet 2005). On the other hand, granting of AOC can lead to opportunistic behaviour of winemakers in terms of lowering their production standards, which can lead to large differences in the quality of wines and therefore damage the reputation of the cluster (Migone and Howlett 2010).

Slovakia can draw inspiration from the export success example of the so-called New World producers (countries outside Europe), which have entered the global wine market in the 1970s and 1980s. Countries such as Australia, Chile or New Zealand proved that export-oriented strategy positively correlates with the success of their wine clusters (Migone and Howlett 2010). Nevertheless, limitations of innovation due to the different historical background could form an obstacle to the implementation of the successful New World cluster model in Europe.

According to 2010 - 2011 survey of the most important wine producers in the Southern Hemisphere (Argentina, Australia, Chile, New Zealand), main reasons for cooperation in the wine industry are attracting new customers and long-term increase of sales (Felzenstein 2012).

Aylward (2004) found that a positive correlation between innovations, export orientation and close connections with industry organizations (Cooperative Research Centre for Viticulture and the Australian Wine Research Institute) can be observed in the South Australian wine cluster.

Based on 2003 survey of 28 experts involved in the governance of the Chilean wine cluster, marketing and promotion, innovation and internationalization were the biggest obstacles restraining the industry competitiveness. Marketing and promotion and internationalization are also the fields with the biggest collective action problems. As for marketing, the main issue was the image of Chile as a low cost producer for popular premium and premium market segments. The need to built up „Brand Chile“ was recognized in order to improve the image of Chilean wines abroad. Wine is the first consumer product from Chile that succeeded on the world markets. Brand Chile may therefore pave the way for the export of other Chilean products (Visser 2004).

The export strategy seems to be correlated with the success of the New World clusters, at least in the cases of Australia, New Zealand and Chile (Visser 2004). Relatively strong correlation can be observed among the well-developed organizational or associational structure of the wine industry, strong export orientation and small domestic market (Migone and Howlett 2010). Clusters could encourage exports by creating greater export and brand awareness among its members and provide conditions conducive to international marketing (Aylward 2004).

High export volumes are not the necessary condition of export success, as shows the example of New Zealand: even though its export volumes are limited, they show the highest average prices in the international markets (Migone and Howlett 2010). Marketing strategy of the New Zealand wines is niche-focused, aimed at high-quality positioning (Felzenstein 2012).

One of the classic examples of successful wine clusters (mentioned in the 1998 Porter article Clusters and the new economics of competition) is the California wine cluster, which is orga- 
nized around grape growers and winemakers. Companies and institutions providing goods and services play also an important role, as well as government, educational and research institutions. Thus, both horizontal and vertical links among its members can be observed. The cooperation of winemakers dates back as late as 1881, when they established Napa Valley Viticulture Society (Migone and Howlett 2010).

Wine cluster can provide a boost for the regional economy, as can be observed in the Rioja wine cluster in Spain. According to the study covering 180 wine companies and 50 suppliers, $77 \%$ of the wineries' expenses went to the companies in the region (Migone and Howlett 2010). The wine cluster directly employs roughly 14000 people, indirectly provides income for other 20000 people. The production is focused on high quality wines, based on the specific local vinification method. In the Rioja region, the establishment of the new wineries fuels the development of other sectors, such as machinery construction, engineering or architecture. The development of these supporting industries is thus linked to the development of wineries (Lareina, Gómez-Bezares and Aguado 2011).

Růžičková and Korab (2013) conducted a research on the effect of the V8 winemakers alliance membership on the companies' performance which was measured by the comparison of alliance member and non-member companies value development. Both types of firms operate in the Czech Republic without foreign investment. The motives for the creation of an alliance were as follows: coordination of the marketing activities in the Czech Republic and abroad, know-how sharing, common sales policy in the foreign markets and improvement of quality. Results show that the value of all the alliance members has increased significantly, while the non-members rise in value was less significant, one company even experienced a value decrease.

\section{iii. Methodology and results of the research}

According to information about wine clusters and marketing alliances abroad, our own research was conducted. The research was focused on investigation of the role of clusters and marketing alliances in Slovak wine industry. The aim of the research was to find out the situation in the Slovak viticulture in terms of the existence of cooperation between various actors.

At the beginning of the research, the questionaire consisting of 17 questions was created. An e-mail with a request to fill in the questionaire was send to 600 selected companies and winedressers in Slovakia. The chosen respondents were members of Malokarpatská wine route, Požitavská wine route, Tokajská wine route and Wine route Záhorie. The rest of the sample was either selected from European databank database (Európska databanka - Business to business provider 2013) or found by browsing the internet forums about wine and vineculture. Respondents were requested (three times) by e-mail to fill in the questionaire. At the end of the questioning, 67 completed questionaires were received. A request with a weblink to survey was placed at webpage http://www.vino.sk/forum.html, too. This webpage is displayed as the first in a row when entered the term "víno" (Slovak equivalent for "wine") into a web browser.

During the survey, considerable indifference of the surveyed could be noticed, with regard to the return rate of $11.17 \%$. Respondents had a chance to admit to their identity. Larger companies (more than 50 employees) did not make use of this opportunity, they rather wanted to stay in anonymity.

Considering the structure of respondents, the majority $-71.64 \%$ belong to micro companies. $16.42 \%$ of respondents are small enterprises and $11.94 \%$ are medium companies. In structure of respondents, large companies with more than 250 employees are not included. 


\section{How many employees does your company have?}

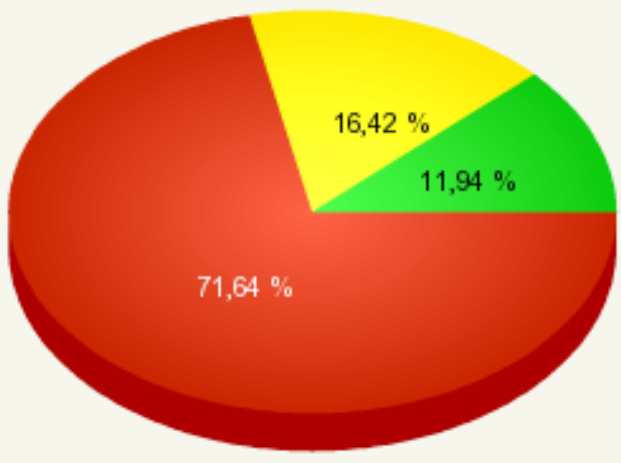

0-10: $48(71,64 \%)$

ㅁ11-50: $11(16,42 \%)$

ㄷ 51-250: $8(11,94 \%)$

zdroj: http://market-aliancie-vinarsky-pri.vyplnto.cz

\section{Source: Own research}

FIGURE 1. NUMBER OF EMPLOYEES

Most of the respondents were active in winemaking (74.34 \%) and viticulture (64.18\%). Other frequencies could be seen in Figure 2:

What is the field of your business activity?

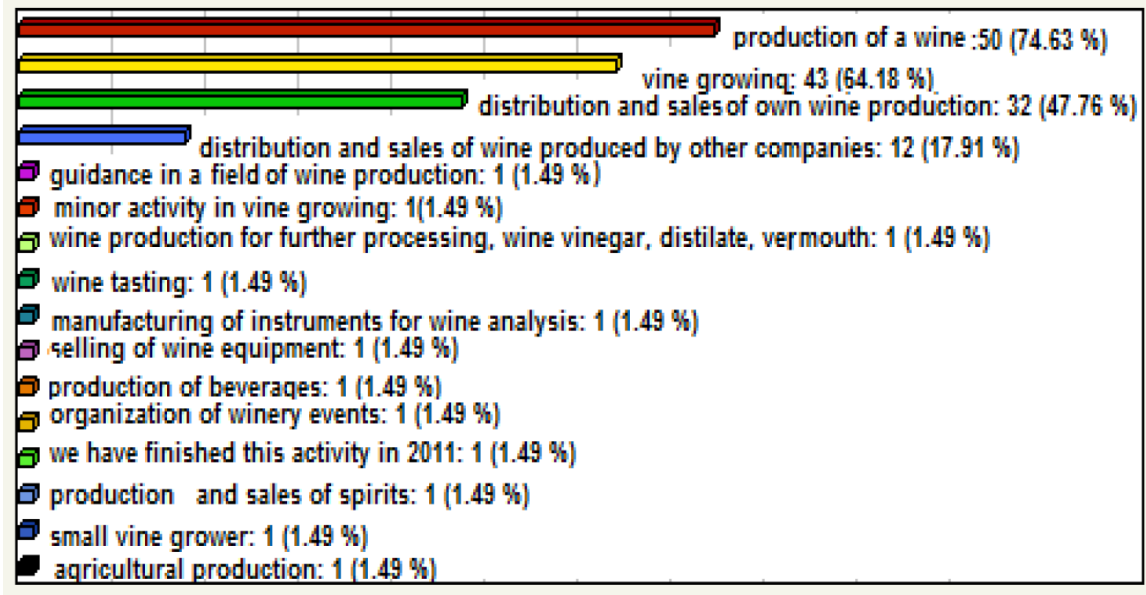

$\begin{array}{lllllllllll}0 \% & 10 \% & 20 \% & 30 \% & 40 \% & 50 \% & 60 \% & 70 \% & 80 \% & 90 \% & 100 \%\end{array}$

FIGURE 2. THE FIELD OF BUSINESS ACTIVITY OF RESPONDENTS 
Of the 67 entities that filled in the questionaire, 21 (31.34\%) export their products abroad. Difficult foundation of the distribution channels $(30.43 \%)$ and insufficient amount of products that could be exported ( $26.09 \%$ ) were cited as the most important barriers of export. It is noteworthy that $30.34 \%$ of respondents that do not export their products is not even interested in export at all.

What is the largest barrier, that inhibit you from exporting your products?

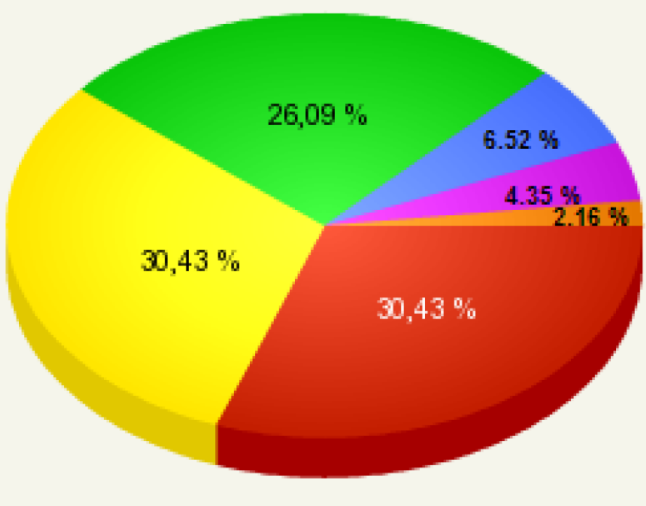

$\square$ Difficulty of foundation of sales channelsin the foreign markets: 14 (30.43\%)

$\square \quad \mathrm{I} \mathrm{am}$ not interested in exporting my products: 14 (30.43\%)

$\square$ Insufficient amount of products that might be assigned for export:12 (26.09\%)

$\square$ The high costs of export: $3(6.52 \%)$

$\square$ Ignorance of foreign markets: 2 (4.35\%)

$\square$. High risk of financial losses: 1 (2.14 \%)

zdroj: http://market-aliancie-vinarsky-pri.vyplnto.cz

FIGURE 3. THE LARGEST BARRIER THAT INHIBIT COMPANIES FROM EXPORTING THEIR PRODUCTS

Source: Own research

$35.81 \%$ of respondents think that the cooperation with other Slovak company could increase the awareness of their products among the consumers abroad, $28.36 \%$ stated, that such cooperation could lower the export costs and speed up the market entry. Nevertheless, $37.31 \%$ of the surveyed is convinced that cooperation would not help them at all. 


\section{Do you think that the cooperation with another Slovak wine company would help you to:}

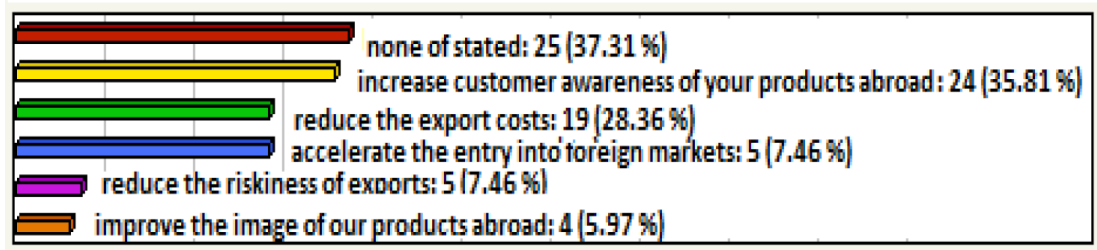

$\begin{array}{lllllllllll}0 \% & 10 \% & 20 \% & 30 \% & 40 \% & 50 \% & 60 \% & 70 \% & 80 \% & 90 \% & 100 \%\end{array}$

FIGURE 4. OPINION ON THE COOPERATION WITH ANOTHER SLOVAK WINE COMPANY Source: Own research

As for the willingness to create a marketing alliance of Slovak wine companies in order to facilitate exports, $65.67 \%$ of the surveyed would incline to such solution.

\section{Would you agree with a creation of a marketing alliance of Slovak wine companies to facilitate export?}

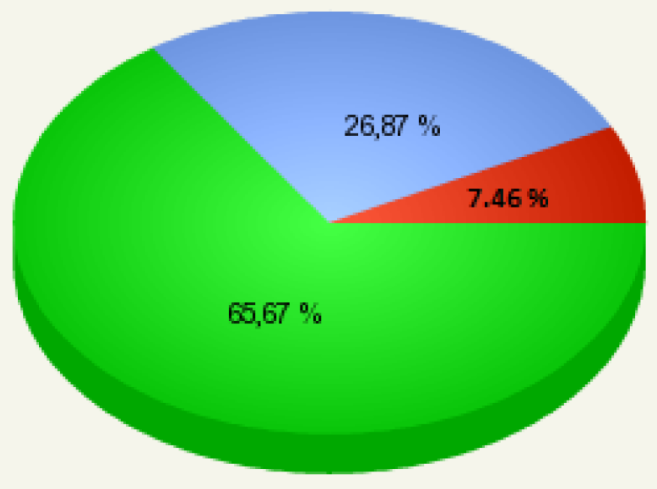

$\square$ yes: $44(65.67 \%)$

$\square$ no: $18(26.87 \%)$

$\square$ I don't know: 5 (7.46\%)

zdroj: http://market-aliancie-vinarsky-pri.vyplnto.cz

\section{FIGURE 5. OPINION ON A CREATION OF MARKETING ALLIANCE OF SLOVAK WINE COMPANIES}

\section{Source: Own research}

A vast majority ( $85.07 \%$ ) of the respondents considered joint marketing strategy useful for raising awareness about Slovak wines in foreign markets. This consensus could provide a base for the cooperation of the wine industry members and eventually for the creation of their marketing alliance. 


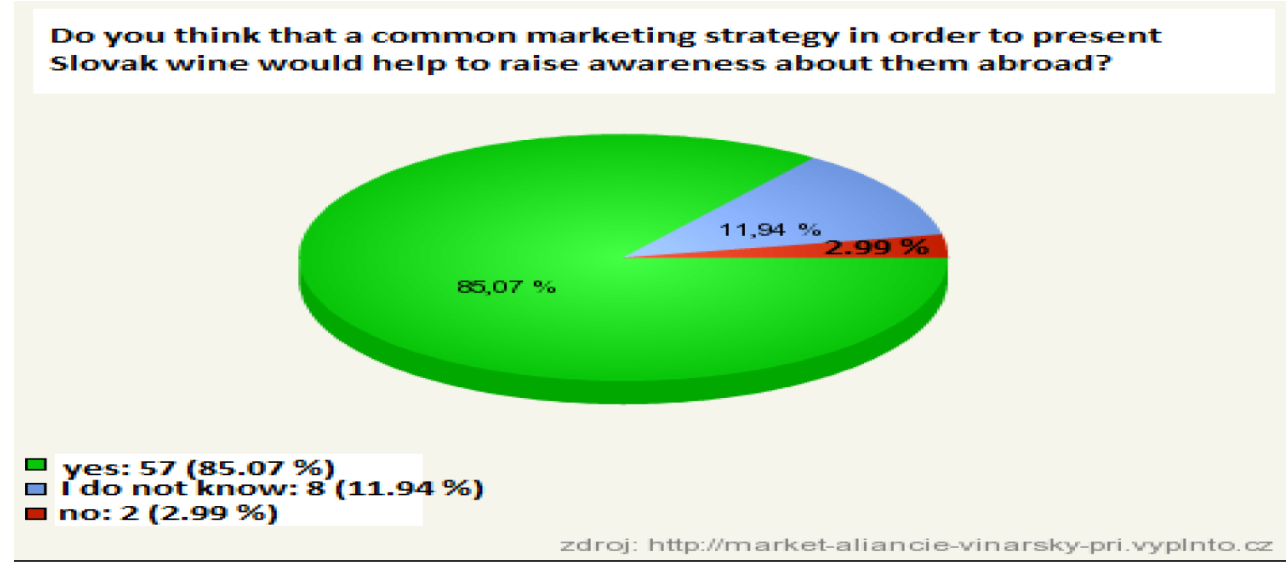

\section{FIGURE 6. OPINION ON COMMON MARKETING STRATEGY OF SLOVAK WINERIES} Source: Own research

$76.12 \%$ of respondents shared the opinion that the creation of the nationwide or regional wine clusters could have a positive impact on the competitiveness of Slovak wine industry. Again, the majority of the sample seems to be willing to cooperate in order to achieve common benefits.

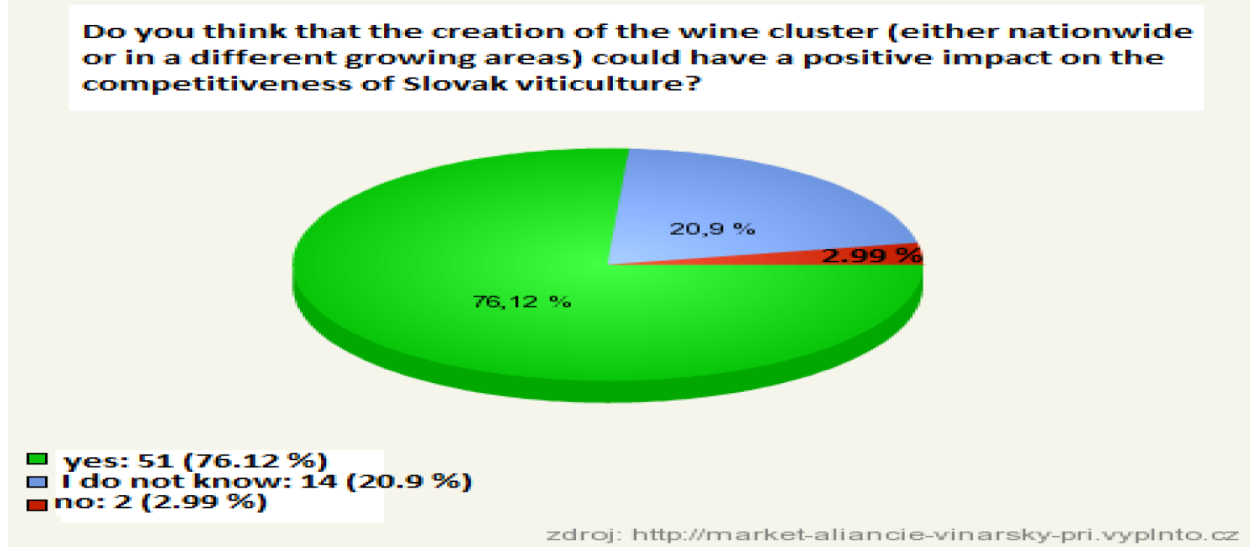

\section{FIGURE 7. POSITIVE IMPACT OF CREATION OF A WINE CLUSTER ON THE COMPETITIVENESS OF SLOVAK VITICULTURE}

Source: Own research

According to survey, wine producers should definitely be a major part of the wine cluster in Slovakia ( $94.03 \%$ of respondents). Other frequencies are visible in the figure 7 : 


\section{Who (according to your opinion) should be a part of your cluster?}

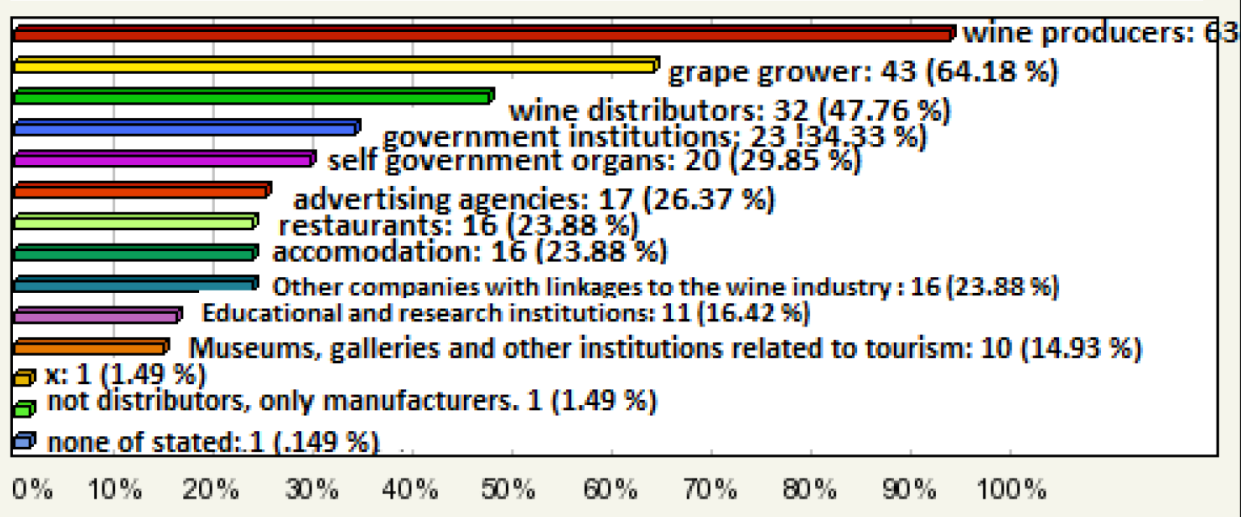

FIGURE 8. POTENTIAL MEMBERS OF A WINE CLUSTER

Source: Own research

One of the last questions of the questionaire examined, how were the respondents affected by the financial and economic crisis. The answers were different - considerable amount of respondents said that they weren't affected by financial and economic crisis at all and didn't feel any changes in their business. Other respondents stated that they have lost time and money or that they have to do more now than in past just to earn the same amount of money. A few respondents noted that crisis had a positive effect on their business - costs of inputs were reduced while sales weren't affected. On the other hand, respondents evaluated negatively the changes in the Labour Code in Slovakia which entered into force in January 2013 and may have caused higher unemployment, but definitely increased the tax burden. Respondents saw the decrease of purchasing power as a significant problem. Nevertheless, excessive increas in the cost of inputs, poor bargaining position with wholesalers and retail chains, decrease in the sales of wine, inadequate support of state bodies and government and sales resistance in a field of grown grapes were perceived as serious problems caused by the crisis. 


\section{CONCLUSION}

According to the results of the survey, entities active in the Slovak wine industry recognize the opportunities and benefits of cooperation. The majority of the respondents think that creation of a marketing alliance could facilitate export and that forming of a cluster could improve the competitiveness of Slovak wines. The cooperation within the joint marketing alliance of winemakers and other entities involving suppliers, research institutions, universities and even customers could possibly be the beginning of an institutionalized wine cluster. For the small and medium enterprises (which form the majority in the Slovak wine industry), it is especially difficult to entry and succeed on the foreign markets, given their limited resources. Joint marketing alliance of winemakers can reduce the costs and improve their chances of penetrating into the new markets. Vast majority of respondents agreed that the common marketing strategy could improve the consumer awareness in the foreign markets. Appelation of origin, namely "Country of origin" or "Region of origin" could be one of the benefits of marketing alliance for its members. The value of this appelation would be derived from the reputation of the participating companies. Therefore, the "Brand Slovakia“ in wine industry should be based on the successes and quality of particular wines and their producers (e.g. nine gold and nine silver medals at the Bacchus competition in Madrid or 9 gold medals from Vinalies Internationales in Paris, both contests being held in 2013).

The survey showed that the willingness to cooperate exist in the Slovak wine industry, even among the competitors. By the medium of coopetition, Slovak wineries could be able to enter the new markets successfully, as was the case of some of the New World producers (e.g. Chile or Australia) that are now ranked among the biggest wine exporters in the world. 


\section{REFERENCES}

Aylward, David K. 2004. "Wine Clusters Equal Export Success." Accessed March 27, 2013. http:// ro.uow.edu.au/cgi/viewcontent.cgi?article=1082\&context=commpapers.

BIC Bratislava. 2013. "O nás." Accessed April 6, 2013. http://www.bic.sk/.

Calvet, Jacques. 2005. "Nature and problems of French wine clusters." Accessed March 26, 2013. http://academyofwinebusiness.com/wp-content/uploads/2010/05/NatureAndProblems. pdf.

Chlebíková, Darina, and Janka Mráziková. 2009. "Clusters - a New Form of Regions Development in Slovakia." Accessed April 7, 2013. http://www.um.ase.ro/No11/11.pdf.

CluStrat. 2013. "The Union of Slovak Clusters." Accessed April 7, 2013. http://clustrat.eu/consortium/partners/uks/.

CluStrat. 2013. “Clustrat New Cluster Concepts for Central Europe.” Accessed April 7, 2013. http:// www.clustrat.eu.

Danube knowledge cluster. 2013. "Definition of a Cluster." Accessed April 7, 2013. http://www. dkc-eu.com/en/pages/danube-knowledge-cluster.

Das, T.K., and Bing-Sheng Teng. 2000. „A Resource-Based Theory of Strategic Alliances.” Accessed April 1, 2013. http://aux.zicklin.baruch.cuny.edu/tkdas/publications/das-teng_jom00_resourcebasedtheory_31-61.pdf.

European Commision. 2013. "Industrial innovation - Clusters." Accessed April 7, 2013. http:// ec.europa.eu/enterprise/policies/innovation/policy/clusters/.

Európska databanka - Business to business provider. 2013. Accessed March 20, 2013. http:// www.edb.sk/.

Felzenstein, Christian. 2012. "International Marketing in Southern Hemisphere Wine Clusters." Accessed March 25, 2013. http://www.clusterinnovation.com/doc/International\%20Wine\%20Clusters\%20Southern\%20Hemisphere-\%20BALAS\%20presentation $\% 20$ April\%202011.pdf.

Felzenstein, Christian, Deans, Ken, Echecopar, Germán. 2012. „Marketing Strategy, Innovation and Externalities: The Case of the Chilean Wine Cluster." Accessed March 26, 2013. http:// www.clusterinnovation.com/doc/Wine\%20clusters\%20Chile\%20-\%20BALAS\%202011. pdf.

Ferenčíková, Soňa, Pappová, Alexandra, Hlušková, Tatiana, Vícenová, Alena, Krajčík, Daniel, Ferenčíková, Soňa, Pásztorová, Janka. 2013. Medzinárodná expanzia firiem: stratégie, partnerstvá a ludské zdroje. Bratislava : lura Edition.

Larreina, Mikel, Gómez - Bezares, Fernando, Aguado, Ricardo. 2011. “Development Rooted on Riojan Soil: The Wine Cluster and Beyond." Accessed March 25, 2013. http://www.benthamscience.com/open/togeogj/articles/V004/SI0001TOGEOGJ/3TOGEOGJ.pdf .

Migone, Andrea, and Michael Howlett. 2010. "Comparative networks and clusters in the wine industry." Accessed March 27, 2013. http://www.wine-economics.org/workingpapers/ AAWE_WP62.pdf. 
MSP online. 2012. „Rozvoj klastrov na Slovensku.“ Accessed April 7, 2013. http://msponline.sk/ content/rozvoj-klastrov-aj-na-slovensku.

Mueller, Rolf. A. E., and David A. Sumner. 2006. "Clusters of Grapes and Wine." Accessed March 24, 2013. http://www.agmrc.org/media/cms/Wine_Clusters2_84CD1EE476398.pdf.

OECD. 2002. "Glossary of Statistical Terms." Accessed April 6, 2013. http://stats.oecd.org/glossary/ detail.asp?!D=3614.

Porter, Michael. 1998. "Clusters and the New Economics of Competition." Accessed April 6, 2013. http://hdrnet.org/349/1/porter.studie.pdf.

Růžičková, Kamila, and Petr Korab. 2013. "Does horizontal cooperation create value? A residual income approach application on Czech agricultural data." Accessed March 22, 2013. ftp:// ftp.mendelu.cz/RePEc/men/wpaper/32_2013.pdf.

SIEA. 2009. "Klastrové iniciatívy pôsobiace na Slovensku." Accessed April 7, 2013. http://www.siea. sk/klastre-na-slovensku/.

SIEA. 2010. "Klastrovanie - Predpoklad úspechu." Accessed April 7, 2013. http://www.siea.sk/materials/files/inovacie/slovenske_klastre/SIEA-brozura-Klastrovanie.pdf.

Šmíd, Jaroslav. 2008. "Súčasná situácia a skúsenosti so zakladaním klastrov na Slovensku." Accessed April 7, 2013. http://www.nanosvet.sk/_paper/Sucasna_situacia_a_skusenosti_so_ zakladanim_klastrov_na_Slovensku_01.pdf.

Teng, Bing-Sheng, and T.K. Das. 2008. „Governance structure choice in strategic alliances." Accessed March 23, 2013. http://aux.zicklin.baruch.cuny.edu/tkdas/publications/teng-das_ md08_GovernanceStructureChoicelnSAs_725-742.pdf.

Visser, Evert-Jan. 2004. "A Chilean wine cluster? Governance and upgrading in the phase of internationalization." Accessed March 27, 2013. http://www.cepal.org/publicaciones/ xml/8/20498/LCL2138.pdf.

\section{ACKNOWLEDGMENT}

The paper is part of the research project: VEGA project No. 1/1185/12: Consumer trends changes conditioned by the financial-economic (social) crisis impacts, their reflection in modifications of the business entities' marketing programmes in an effort to retain their competitiveness in the international markets (application on the EU conditions with the accent on Slovakia). (Head: doc. Ing. Otília Zorkóciová, PhD. Workplace: Department of International Trade - Faculty of Commerce).

The paper is part of the research project: VEGA project No. 01/0461/12 - Management competence in foreign and domestic companies in Slovakia as a source of increasing their competitiveness in the era of the globalising economy (Head: Prof. Ing. Soňa Ferenčíková, PhD.). 